University of North Florida

UNIVERSITY of

NORTH FLORIDA.

UNF Digital Commons

Teaching, Learning and Curriculum Faculty

Publications

Department of Teaching, Learning and

Curriculum

Spring 2020

\title{
Collegiate Cultural Capital and Integration into the College Community
}

John W. White

University of North Florida, j.white@unf.edu

Steven Aragon

Amanda Pascale

amanda.pascale@unf.edu

Follow this and additional works at: https://digitalcommons.unf.edu/etlc_facpub

\section{Recommended Citation}

White, John W.; Aragon, Steven; and Pascale, Amanda, "Collegiate Cultural Capital and Integration into the College Community" (2020). Teaching, Learning and Curriculum Faculty Publications. 1.

https://digitalcommons.unf.edu/etlc_facpub/1

This Article is brought to you for free and open access by the Department of Teaching, Learning and Curriculum at UNF Digital Commons. It has been accepted for inclusion in Teaching, Learning and Curriculum Faculty Publications by an authorized administrator of UNF Digital Commons. For more information, please contact Digital Projects.

(c) Spring 2020 All Rights Reserved

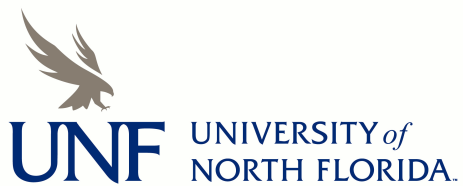




\section{Corresponding Author:}

John W. White

$57 / 2321$

Department of Teaching, Learning, and Curriculum

University of North Florida

1 UNF Drive

Jacksonville, FL 32224

j.white@unf.edu

\section{Collegiate Cultural Capital and Integration into the College Community}

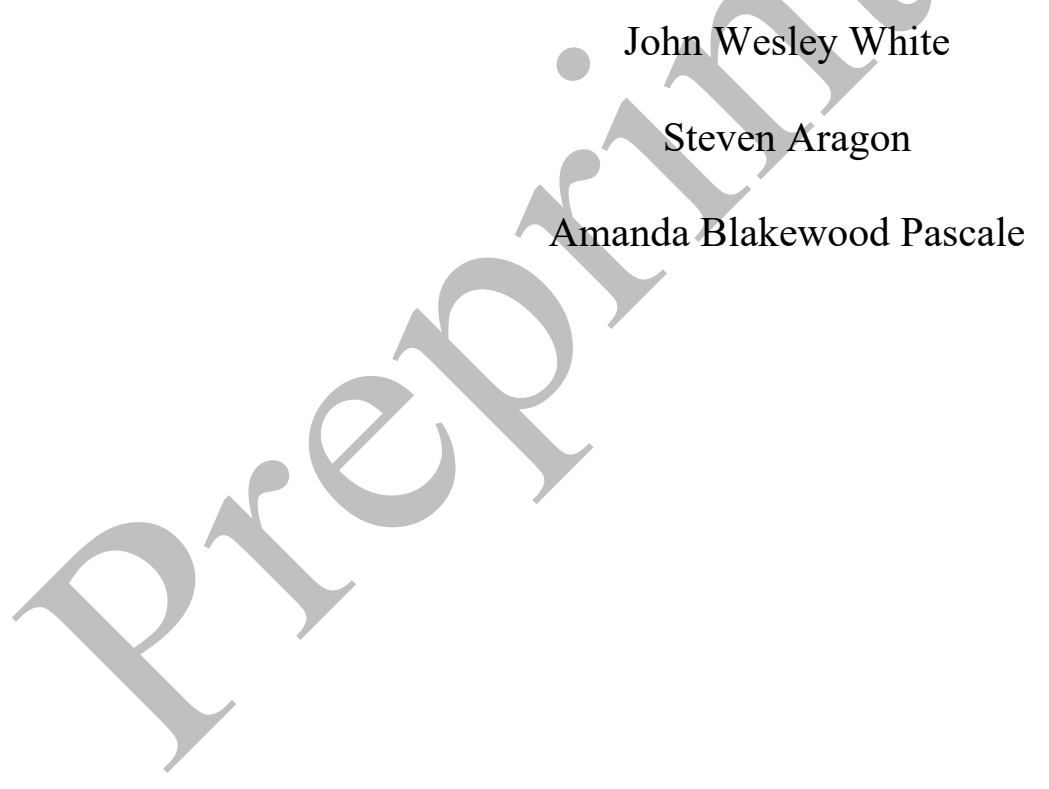




\begin{abstract}
Preventing attrition for racially minoritized, first-generation, and low SES postsecondary students continues to be a challenge despite significant efforts of educational researchers, college administrators, and high school teachers and counselors. Cultural capital (skills necessary to successfully navigate an environment) may help to explain and address this issue. Applying cultural capital and college readiness frameworks, we attempt to better understand the challenges four racially minoritized, first-generation, low-SES students face in attempting to get a "read" (understand the workings) on college. Students were in their second semester of their first year and on academic probation. Each participated in interviews and journal writing throughout one semester. Analysis revealed that cultural capital served as a foundation for reading the college environment in four key areas required for college readiness: understanding and calculating GPAs; computer literacy required for completing assignments; understanding the course listing and registration process; and finding other campus resources for addressing needs.
\end{abstract}




\section{Collegiate Cultural Capital and Integration into the College Community}

"I just can't get a read on this place...You know, I'm still wet behind the ears and I don't know much man. I came from a place where I hardly even knew that this system [university culture] existed"

- Simon, first-generation, Native-American first year college student

Evidence suggests that Simon's experience is not unique; rather, it represents the struggle that many racially minoritized, first-generation and low social economic status (SES) college students face in being able to "get a read" on what is expected of them in college. Many racially minoritized, first-generation, and low-SES college students transitioning from high school to college start the latter with limited and insufficient knowledge about college social and academic culture and thus how to prepare for their first term (Tierney, 2013; Tierney \& Colyar, 2009). While the college admissions vetting process virtually guarentees that enrolled studentsregardless of race, parental educational attainment, cultural background, prior educational experiences, or academic ability — are literate in the literal sense of the word, many lack the form of college readiness we refer to as collegiate academic literacy. While college students individually bring a wealth of prior experiences and academic strengths, too many, particularly those who are first-generation, from racially minoritized, or low-SES backgrounds, arrive on campus with an inadequate understanding of the underlying structures and rules associated with the college community, and with the institutional norms that contribute to a more complete and useful collegiate academic literacy. Not being fully versed in academic literacy, these students have fewer opportunities to become what Lave and Wenger (1991) call "full participants" (p. $105)$ in the culture in which they find themselves. First-generation students, in particular, often have both less overt knowledge and tacit knowledge about what college academic and social cultures entail (Kuh, Kinzie, Buckley, Bridges, \& Hayek, 2007). For myriad reasons, these students have had fewer opportunities to develop collegiate academic literacy prior to enrolling 
in college. This, in turn, means that once in college they have a less developed foundation on which to build new collegiate academic literacy.

Using a cultural capital framework, the purpose of this paper is to examine how college campus practitioners can build infrastructure that better supports the growth and development of acadmic literacy and collegiate cultural capital. The following research questions guided this study: (1) What forms of academic capital do racially minoritized, first-generation, and low-SES students bring with them to college? (2) How do racially minoritized, first-generation, and lowSES college students describe their academic identity? (3) What are the essential components of "collegiate academic literacy"? The examples described below support the notion that soley providing access to the academy for youth from disadvantaged backgrounds is not enough, we must also continue to find ways to provide support systems within higher education that will allow for the growth and success of all students.

Before we begin, however, there is a critical issue that we would be remiss in ignoring: what may appear to some readers to be the lens of deficit theory (a focus on what groups of students lack rather than on what unique talents they bring to school) in examining a complex problem. While we fully acknowledge that all students come to college with many strengthsstrengths that are too seldom welcomed or appreciated in mainstream college academic and social cultures-we also recognize that many mainstream institutions (including colleges) nonetheless require specific overt and tacit skills. Academe is a discourse community and as such it expects specific norms of the participants therein (Bizzell, 1992; Lave \& Wanger, 1991; Swales, 2016). Our goal in this paper is not to critique a group as lacking, but rather to note a few forms of collegiate cultural capital that, despite their importance to collegiate success, tend to remain part of what Eliot Eisner defines as the null curriculum: "the options students are not 
afforded, the perspectives they may never know about, much less be able to use, the concepts and skills that are not part of their intellectual repertoire" (1985, p. 107). Thus, describing how and why some racially minoritized students, first-generation students, or students from low socioeconomic backgrounds lack certain forms of collegiate capital is not a critique of the students themselves, but is, in some ways, an indictment of the rigidity of the college institution itself, and the failure of K-12 schools to adequately prepare everyone for college success (Balduf, 2009; Charles, 2018; Gewertz, 2017; National Center for Educational Statistics, 2017; Reid \& Moore, 2008; Sheehy, 2012). However, criticism alone, is not enough to foster change. We posit that change is most meaningful and effective when it orginiates from within; to this end, only when the academy itself contains a greater multiplicity of voices and views will it become more appreciative of the forms of capital that diverse students bring.

\section{Background}

\section{Racially Minoritized, First-Generation, Low-SES Students in Higher Education}

Racially minoritized students received only $33 \%$ of the nearly 1.9 million bachelor's degrees awarded during the 2013-2014 academic year despite higher enrollment in college, an increase from $24 \%$ of 1.7 million bachelor's degrees awarded in the 2007-2008 academic year (Kim, 2011, NCES, 2017). While the majority of U.S. $9^{\text {th }}$ grade students expect to go to college (Aud et al., 2010; Aud, KewalRamani, \& Frohlich, 2011), only 33\% of those high school seniors in the lowest SES quartile are expected to complete a bachelor's degree compared to $39 \%$ in the middle two quartiles and 35\% in the highest quartile (Aud et al., 2011). The issue is further complicated when correlated with parental educational achievement: of the low SES students enrolled in college between 1992 and 2000, those who had a parent or parents who completed college graduated at a rate of $68 \%$; that number drops to $43 \%$ for first-generation students (Chen, 
2005). This trend is still present now, with $42 \%$ of continuing generation college students graduating and only $20 \%$ of first-generation college students graduating (Redford \& Hoyer, 2017). Further, the data are clear, the attrition rate for college students with one or more of these socio-demographic characteristics continues to far exceed that of their more advantaged peers. There are abundant and well-documented reasons for this.

The most commonly cited reason - and the focus of the earlier research on racially minoritized and low-SES student attrition — is that these students are less likely than their White peers to be academically prepared through their previous academic experience for the demands of college-level coursework, and thus drop out due to academic failure (Falcon, 2015;Adelman, 2006; Zarate \& Gallimore, 2005). Inequitable K-12 school funding, tracking into low ability groups, lowered teacher expectations (deficit theories), and punitive behavioral management all negatively affect minoritized student academic performance and preparation for college more than they do White students (Oakes, 2005; Oakes, Rogers, \& Lipton, 2006; Solorzano, Ledesma, Perez, Burciaga, \& Ornelas, 2002).

There is also a relationship between attrition and racially minoritized students' perceptions that college campuses are oftentimes hostile places, a perception that is backed up by many examples of overt and tacit racism and classism on campuses (Quaye, 2007; Schmidt, 2008). Reinforcing this perception are cultural incongruences between racially minoritized and low-SES college students and their peers and professors (Marcus et al., 2003; Nuñez, 2009; Ortiz, 1999,2000). Furthermore, lack of culturally-relevant peers and faculty role models contributes to diffult transitions to college (Pyne \& Means, 2013; ACT Policy Report, 2002; Perna, 2000). While off campus they have fewer college-educated relatives who can serve as academic or social mentors (Falcon, 2015; ACT Policy Report, 2002; Perna, 2000; Swail, Redd, 
\& Perna, 2003). Finally, students from disadvantaged backgrounds tend to face significant burdens in paying for rapidly rising college costs (Falcon, 2015; Conley, 2001, 2008; Finegold \& Wherry, 2004). Though this body of research elucidates a bevy of factors affecting attrition for students from disadvantaged backgounds, a lesser emphasis is placed on the role that academic literacy, as a form of collegiate cultural capital, plays in students' integration into and success within the academy.

\section{Academic Literacy and Collegiate Cultural Capital}

Research examining students' identity issues and cognitive development as related to their knowledge and uses of literacy and discourses (Lakoff \& Johnson, 1980; Lave \& Wenger, 1991; Vygotsky, 1986) suggests many first year college students leave their high schools lacking a collegiate-level academic literacy (Author Citation). By academic literacy, we refer to the types of discourses commonly expected within the university community (itself a discourse community a la Lave and Wenger, 1991) and especially within classrooms and between students and faculty. To be fully understood in academic discussions and communications (and to be accepted as a legitimate participant in such discussions), one must be familiar with and able to use the discursive norms of the academy. This body of research emphasizes that the development of strong collegiate academic literacies is predicated upon students gaining an understanding of the basic workings of the college system, which should come through their P-12 educational experiences. Like the development of all forms of literacy, academic literacy requires a solid foundation on which to build. The development of more nuanced and complex forms of discourse rely on an understanding of the basic structures around which such discourse is builtthe general structure of the society (and its hierarchies), the vocabulary unique to the context, the basic 'rules' and operations of the communities, prefered modes of communication, etc. (Lave \& 
Wenger, 1991). In other words, because more advanced forms of discourse are so closely tied to contexts, those wishing (or needing) to employ said discourses must understand the structures around which discourses have formed (much as one must understand the referents to understand a metaphor).

'Reading' an environment requires what all other forms of effective reading require: prior knowledge (McNamara \& Kintsch, 1996; Tarchi, 2010). As Paolo Friere stresses in Literacy: Reading the Word and Reading the World (Freire \& Macedo, 1987) one must be able to "read the world" if one is to "read the word" in any meaningful way (p. 32); conversely, being ill equipped to read one's surroundings and contexts is likely to lead to oppression. Unfortunately, structural barriers prevent many racially minoritized, first-generation, and low-SES students from entering college without an understanding of some of the most rudimentary workings of academic and college culture that, in turn, inhibits their ability to develop new and nuanced knowledge.

Acquiring "capital" to read and succeed. The notion of collegiate cultural capital draws on the theoretical underpinnings of Bourdieu (1886) and Delpit (1995)., Bourdieu (1986) posits there are four different kinds of capital one must possess in order to find full acceptance in a given community; economic capital refers to the material goods and resources needed for one to be able to buy their way into a particular community; cultural capital refers to the institutionalized capital,(e.g., academic qualifications, certifications, and other credentials) one must possess to gain entrance to a community; social capital refers to access to and membership in particular cultural and sub-cultural social groups and institutions via participation in ceremonies and rituals; symbolic capital refers to one's capacity to satisfy the authorities who sanction or authorize "legitimate identity" (p. 75) in a community. Taken together, Delpit (1995) 
termed the foundational junctions of Bourdeiu's four types of capital, cultural capital. Within the the collegiate setting, full participation and success in the university community requires differing levels and types of cultural capital. Conversely, the absence of, or inadequacy with, any of these forms of cultural capital created through inequitable school experiences largely predicates failure within and, in some cases, withdrawal from the academy (Kutz, 1998; Nettles \& Perna, 1997; Author Citation). In college, for instance, information, strategies, and skills allow students to successfully navigate the complex processes of financial aid and registration, or develop an understanding of college norms, expectations, and diverse cultures (Barnes, Slate, \& Rojas-LeBouef, 2010; Conley, 2008). However, though students from disadvantaged backgrounds often enter with a host of life experiences that contribute positively to the development of skills essential for college readiness (Byrd \& Macdonald, 2005), they may be under prepared to navigate complex systems of higher education. More specifically, many students arrive on campus without the economic, cultural, social, and symbolic capital (Bourdieu, 1986, 1991) needed to survive therein. In short, they have not had opportunities to aquire what Bourdieu termed 'habitus', that is the internalization or normalization of specific funds of knowledge that serve as a basis for survival in a given environment (Bourdieu, 1986). Speaking specifically to the needs of students from low-SES communities, Rendon (1999) states, "the problem is not so much that low-income students lack ambition, it is that these students have not received the socialization, encouragement, or mentoring to take full advantage of higher education" (p. 197).

\section{Method}

Multiple case study design was used and predicated upon a constructivist approach (Miles \& Huberman, 1994; Stake, 1995; Yin, 2014) to explore students' creation of meaning of 
their academic experiences and development of their academic identity as well as the types of cultural capital they possess. This methodology was appropriate given the multiple levels of context (e.g., individual's internal context, family context, school context and the broader social, economic and policy context) that shape student success (Perna \& Thomas, 2006).

\section{Sampling \& Data Collection}

Potential participants were screened for specific criteria. These criteria included, (a) firstgeneration college student status, (b) in the second semester at college, (c) from a minoritized and/or low socioeconomic background, (d) struggling academically (on academic probation due to a GPA below 2.0), (e) voluntarily seeking help from the university's academic services center. For the purposes of participant selection, first-generation status was defined as students whose primary caregiver(s) had not attended a four-year college or university. Students who met all criteria were contacted by telephone, campus mail, and email to gauge their interest in participating. Seven students meeting the basic criteria met with the first author to discuss the parameters of the study and to ask questions; four chose to participate. They included Simon, a Native American male; Latricia, an African American female; Alex, a Hispanic male; and Maria, a Hispanic female (all pseudonyms). Data were collected during the academic semester and included weekly interviews with students and corresponding researcher field notes, journal entries from students, and artifacts.

Interviews. The weekly individual interviews lasted between and hour and an hour and a half. Each student was asked a series of questions about their academic, cultural, and social backgrounds; their expectations for college and the surprises they faced in their first semester; their ideas about their relative strengths and weaknesses, etc. Finally, each of the participants sat for a final, post-study interview where they discussed the results of the intervention 
approaches/practices, their plans for the future, and what forms of capital they felt they developed or recognized during the course of the semester. All interviews were recorded and transcribed.

Journal entries. Student journal entries included their daily thoughts about the college environment or culture, their classes, academic tasks, social life, and any problems they encountered. Journal entries were photocopied for later analysis.

Artifacts. Artifacts included students' written work, comments from and correspondence with professors/instructors, and their personal class notes. In addition, each student's academic progress was monitored via an academic database that included professors' evaluations, midterm exams, and notes from other academic advisors.

\section{Data Analysis}

Using Goetz and LeCompte's (1984) recommendations for initially organizing data, after a general 'read through' of data, we created basic categories of issues. We consulted on items and issues not included in the original categorization plan, and created additional categories as needed. We used this schema to identify themes that were particular for each participant and, more importantly, those themes that were common to all of the participants.

We further analyzed the data collected according to Spradley's (1980) domain and componential analysis, Domain analysis allowed us to focus on those domains that were pertinent to the components of collegiate academic literacy and thereby provide a guide to analyze a wealth of otherwise overwhelming raw data. Next, we created categories of semantic relationships (e.g., $\mathrm{X}$ is an attribute of $\mathrm{Y}, \mathrm{X}$ is a way to $\mathrm{Y} . .$. ) for each issue.

Componential analysis provided a means to compare and contrast different units of cultural meaning and identify otherwise unnoticeable patterns (Spradley, 1980). For example, we 
looked at 'natural discourse patterns' on one axis and another domain such as class participation (or lack thereof) on the other axis.

Member checking occurred with the participants at various points throughout the process (Stake, 1995). After transcription and preliminary analyses had occurred, all participants were given an explanation of the categories, the data obtained from them, and then asked to comment on the initial categories generated at follow-up interviews. Their feedback was subsequently incorporated. Upon completion of the componential analyses and a write-up of our findings, the participants were provided with a draft of the analysis section and again asked to provide feedback on the accuracy of our analyses as they pertained to each individual. With each participant, we discussed the few discrepancies she/he had brought forward and altered the text - in the presence of that participant — to ensure that we captured how they experienced each issue and context. This process helped to ensure the trustworthiness of these data.

\section{Findings}

\section{Cultural Capital as a Foundation for Reading the College Environment}

Although each of these students faced enormous challenges to academic success at the university including, as Simon put it "not knowing how to talk right," many of their problemsincluding learning those linguistic codes common to the collegiate academic setting-resulted from a more basic misunderstanding of the university system itself (for more information on each student's level of academic literacy and the challenges they faced in building that literacy, see Author Citation). Though intelligent and capable, each came to the university unaware of the ways in which students, staff, and faculty are expected to operate within that system; they lacked a foundational institutional literacy. In contrast to most of their peers, our participants had never been exposed to the foundational skills they needed to develop a comprehensive academic 
literacy. More specifically, each of the study participants came to the university not understanding concepts such as cumulative grade point averages (and how to compute them), course forgiveness, how to use email in communicating with professors and university personnel, how to navigate the university's learning management system (online course management software), how to apply for student loans and grants, how to determine the courses in which they needed to enroll and how to undertake the process of enrollment, and where and to whom to go for healthcare and psychological needs. These issues were compounded by these students' lack of study skills, yet another foundational form of academic literacy.

Grade point averages. Understanding the concept of grade point average (GPA) is crucial to knowing one's academic status within the system (Author Citation). However, how grade point averages are calculated (and the ways that one can predict a future GPA via prospective grades), too often remain a part of the null curriculum (Eisner, 1994). Simon and Maria were both on academic probation with GPAs under 2.0, after their first semester at college. Yet neither understood how their previous semester's respective GPAs had been calculated, or what would be required of them to get off of probation. Thus, their academic probation and the potential consequences resulting from probation, was unclear.

Simon, whose GPA had fallen to 1.65 , claimed early in our work together that he felt that improving enough to stay in college was "almost impossible." When discussing his predicament, he said, "[T]here's all these worries in my head. I got to do good or else I'm outta here." His idea of 'doing good' was "I guess I need, like, all A's if I wanna stay here." Misunderstanding how GPAs work, he felt that "no matter how hard I work, that [staying at the university] ain't gonna happen." His misunderstanding compounded his difficulties and his chances for success: "I'm getting these letters all the time [from the Dean of Students]...telling me I got to do better." $\mathrm{He}$ 
had stopped opening university mail because they made him feel "stupid" and "like I don't have a chance [to stay]." Simon was, based upon threats from the University combined with his misunderstanding of the system, preparing himself—very prematurely_for failure.

Unbeknownst to him however, Simon's situation was far from dire. Once taught how to compute GPA, Simon learned that with his current course load he would only need to earn a 2.4 GPA (a $\mathrm{C}+$ average) to get off of academic probation. He also learned how to compute projected GPA scenarios, thus giving him a better understanding of his situation and a feeling of control over his destiny. He said, after learning the truth about his academic standing that "Yeah, I can do that (his emphasis)". Furthermore, he felt great relief: "At least now I know what I gotta do [to stay]."

Maria had an equally naïve understanding of GPA; at the start of her second semester she told me, “I know I didn't do good last semester, but I don't think I did that bad." She went on to say that she felt that "if I do pretty good this semester, like B's and maybe a C, I should be alright." Belying her unjustified confidence was her actual GPA of a 0.333. Once Maria learned about cumulative GPA, she realized that she would need to earn nothing less than an A in each of her semester's classes just to stay at the university. Though Maria was disheartened to learn of the depth of her predicament, she was also better able to prepare herself and her family for what was almost inevitable. She also developed more realistic expectations for herself. At the end of the semester, she said, “I know I didn't do good enough, but it [being dismissed] wasn't a big surprise...I didn't expect all A's." She had, however, improved academically throughout the semester and,thus improved her chances of being readmitted in the future.

Computer literacy. Recent studies have shown computer literacy is crucial for student success in college (Bartholomew, 2004; Henson, 2014; Latham \& Gross, 2008). With the ubiquitousness of personal computers and social networking, computer literacy is a skill that 
college personnel assume students have grasped prior to entering the university (Eisenberg \& Johnson, 2002). Yet, for students from low resourced neighborhoods, there is no guarantee that they have adequate access to computers to practice their computer skills. Schools in lower resourced school districts tend to have fewer and more outdated computers than do schools in high resource environments (e.g., Benson, 2007; Chapman, Masters, \& Pedulla, 2010; Hohlfeld, Ritzhaupt, Barron, \& Kemker, 2008; Valdez \& Duran, 2007). Even in homes where there are computers, students from lower SES backgrounds still tend to have lower levels of computer literacy as compared to those from higher SES homes (Cohron, 2015; Ritzhaupt, Liu, Dawson, \& Barron, 2013; Zickuhr \& Smith, 2012).

Simon and Latricia each came to the university lacking academic computer literacy. They possessed only rudimentary understandings of how to check their respective student tuitionaccounts online, how to access course-related web sites, or how to use email appropriately. Latricia, for example, announced weeks into our work together that she did not know how to access the lecture notes and PowerPoints her professor had put online for a coming midterm exam. She did not know what a URL address was (her professor had provided one in the syllabus) and she did not know how to log in to her university portal, which would have given her access to the course Blackboard site. We quickly discovered that she had failed to get and read important notices sent out to class email lists: "It took me a long time to realize why other students knew stuff, stuff about class, that I didn't know 'till I got there... they were getting emails." Though competent in other electronic media, Latricia was not familiar with this essential college tool. This should not be surprising as she had no need for it before college: "In high school, most of my papers were hand-written. I didn't really have to type at all...teachers told us what we were supposed to do [in class] or gave us handouts [assignment information]." 
Similarly, Simon had trouble accessing his own portal account information and receiving emails. He had never been taught about his "Personal Identification Number" (PIN) or that all of his student accounts were online. Rather, he spent the better part of an entire day trying to get information from various campus departments. In response to his legitimate queries, he felt that university staff generally greeted his questions as if he were lazy or obtuse. This, in turn, fueled his frusatration and anger: "Man, when I realized I'd spent a whole freakin' day trying to get the same stuff that's on the computer, man I was pissed. I wasted so much time... how come no one ever told me about this stuff?"

Course listing and registration. Understanding how to read a course catalog (including required courses, course numbers and sections, prerequisites, and scheduling) and knowing how to enroll for classes are essential skills for college success. Even into his second semester, Simon did not understand college course listings and enrolling for courses; he did not know that beyond their titles, classes are identified by prefix, number, and section—a foundational part of being literate in the college setting (Corson, 2001). Simon had received no exposure to or need to understand the lexicon of course listings or section numbers in his high school because, as he put it, "everything was planned out for me." He added that because "no one expected me to go to college," no one had taught him how to find out what courses to take. Coming from a community in which almost no one went to college (only four out of 800 graduating students from his reservation were enrolled in a four year college or university) he lacked the resource of college mentors or 'insiders' from whom he could seek advice (Act Policy Report, 2002). This proved a huge detriment to him at the university: in his first semester he simply followed his overburdened advisor's lead and trusted his directions: “...he told me what I should take and did it [enrolled him for courses] on his computer." Simon was "waitlisted" in two sections of the 
overenrolled course "The College Experience" (a mandatory class designed to introduce freshmen to basic research skills and the expectations associated with most courses). As spaces opened in the course, Simon was automatically enrolled in two sections. Being unfamiliar with the concept of waitlisting or course sections, Simon simply followed his computer-generated schedule. Due to this misunderstanding, Simon spent the first six weeks of his first semester taking two sections of the same course; he thought that, like his Geography class, the course had two parts (such as a Lab or a Recitation) and that each part had a similar syllabus.

This experience affected Simon in a number of important ways. Not only did it frustrate him because of the extra work he had to do, it made him wonder about his qualifications for being at college. In recollecting the experience, Simon said:

I guess this is how college really is. It's completely confusing. I wondered if I was supposed to be here, 'cause this is college man, the big time. It's supposed to be organized, to be together. They're supposed to know what's going on; they're here to guide us through, and I was told the wrong thing to do.

Not understanding the registration system, Simon had to work much harder than necessary-a situation that caused him significant stress and prompted self-doubt. Compounding the problem was the fact that even after he was told of his mistake, his problems were far from over. Simon had missed the deadline for dropping courses without financial or academic penalty: "they gave me a really hard time about it even though it wasn't my fault." He had to get “special permission" from personnel at the Dean level to override the rules, an endeavor that itself took days, numerous meetings, and that prompted further feelings of embarrassment and shame.

Finding campus resources. Because many first-generation and minoritized students are unfamiliar with college campuses, they often come to campus lacking an understanding of 
campus resources (Author; Byrd \& MacDonald, 2005). An important part of the cultural capital of the university is knowing where to find the networks of helping professionals common to most campuses (Mucowski, 1984). Campus programs such as orientation are designed to help students learn about resources to and foster new connections between students. However, wellintentioned each participant in this study complained that orientation was, from their perspective, “full of fluff” (Simon) or worse, “a touchy-feely waste of time...I didn't learn nothing there that really helped me" (Maria). Lacking college educated parents or friends to whom to turn for advice, they remained 'in the dark' on where to seek help for any number of common collegerelated problems (Act Policy Report, 2002; Author Citation). It is not surprising, then, that when they needed help, with emotional issues, financial issues, or with academics, they did not know to whom to turn for help. As Alex shared, "Until I came to this study and this place (the Student Services Center), I didn't know where I was supposed to go [for help].”

Simon entered college carrying a huge burden: representing fellow Native American people in a positive light and doing well academically to make good use of his reservation's scholarship money. He had been told before leaving for college that he represented Native American people and should therefore serve as a positive example:

My parents would say, 'be careful what you do, because what you do, people - the upper, the majority-will look at you, and what you do or what you say is going to reflect on us.' That's what they always said to me. That kind of stuck into my head, you know?...It [failure] would be bad, man. I mean, like, I'd let them all down, you know? They're expecting me to get it done, to do good. They're even paying for it [through a reservation scholarship]...So, if I have to go home a failure, if I can't survive here and do good, they'll all be disappointed... my little brother and sister couldn't look to me no more. 
The burden of trying to succeed as an outsider on campus - Simon was well aware that he was "like probably the only Indian these people have ever seen in real life" — combined with the burden of positively representing Native American people through academic success, caused Simon to fall into a severe depression. He exacerbated his depression by developing unhealthy lifestyle practices. For example, misunderstanding his peers' hyperbolic claim that they were "studying all of the time," Simon attempted to do likewise. He drank copious amounts of highly caffeinated drinks throughout the day and turned to alcohol and marijuana to "come down" late at night. This, in turn, began to affect his sleeping patterns and his ability to study. He said, early in the study, that "I'm working all of the time, man, but it don't seem to do no good...now I can't sleep much, and then I'm falling asleep in class."

Facing what was later diagnosed as severe chronic depression, Simon suffered for months because he did not know where to go to seek help. To us he lamented the fact that "it's not like there's anything I can do about it anyway...no one cares." Simon did not realize that the student health center offered counseling and psychiatric care (he thought it was just for "sick people, like with colds or the flu and whatnot"). Even if he was aware that he could seek help there, he did not realize that he could afford it; he had avoided the health center because he thought if he lacked the ability to pay, he would consequently turned away. No one told him that services there were included in his tuition. Simon suffered significantly (lack of sleep, heavy drinking, loss of appetite, etc.) and for an extended period because no one taught him about this essential campus resource.

Alex faced similar problems. Being what he called a "double minority" (Hispanic and gay), he was having trouble assimilating into the university environment. For example, he was shocked at the level of homophobia on a "liberal" campus that supposedly celebrates diversity: 
There's all this talk about [the university] being open, being, you know, liberal and all. It's just talk...You can be what you want so long as it's pretty much like everyone else...My friends and me, we stick with our own kind.

Early in his time on campus, Alex started becoming depressed and feeling increasingly isolated. He felt that he had no one with whom he could talk openly. When he was having trouble with his first "real boyfriend," for example, he shared in his journal entry, "I can't think, I can't concentrate. I'm so upset" He went on to write "there's nobody I can talk to." Like Simon, he did not know that there were campus resources he could utilize such as the mental health clinic or the Lesbian, Gay, Bisexual, Transgender (LGBT) Resource Center. Though he had heard of the former, he thought that he could not seek help there because "I don't have the money for it." It was only after he was educated on the availability, costs, and anonymous nature of these services (information he gained through participation in our study) that Alex began therapy and began to feel better. Toward the end of our time together and nearing the end of his first year of college, Alex acknowledged how helpful these resources were to his success: "I'm stronger now... she [his therapist] has been really helpful.” Alex even ended up finding an older, male mentor at the LGBT Center who, he said, "is a good person...someone I can talk to, bounce things off of." Finally, Simon, Latricia, and Alex all lacked a final aspect of cultural capital at the university: knowing where and how to get funding for college and college-related expenses. Each student required external funding to help them pay their way through college. Yet again, they did not have the underlying foundational resources that they needed - in this case the foundational knowledge of and how to successfully navigate the financial aid processes. Alex, who felt threatened by his mother's economic control over his college experience (and her homophobia), wanted financial independence from her. Simon needed a job to supplement his 
reservation scholarship and help pay for summer school. Latricia's primarly caregivers growing up, her grandparents, could not afford to provide her with spending money for life expenses. Finding funding for college is both an integral part of being successful in college and a cause of great stress (Mucowski, 1984). Yet again, these students came to the campus not knowing where to go for help in such matters. Simon, for example, was surprised to find out that there was a financial aid office on campus: “That's all they do there? Do you have to pay for it?" Simon's comment provides another example where knowledge of available campus resources could have helped to ease stress in the process of navigating college.

\section{Summary}

Each of the students came to college lacking what we have termed "basic academic literacy." None of our participants had the cultural capital required for college success. Not only were they not versed in the more traditionally defined literate practices required for college success such as note-taking, reading academic texts, writing, etc. (Walvoord \& McCarthy, 1990; Author Citation), they were largely unfamiliar with the more basic aspects of college life and work. These students, though intelligent and capable, came to college not only lacking what other researchers have defined as "academic literacy," but they lacked the foundational prior knowledge requisite for developing this literacy. If anything, their lack of prior knowledge on which to build academic literacy precluded development of the latter.

\section{Discussion and Implications}

The stories of these four students testify to the need to assess, and in some cases, build levels of cultural capital for college students who are at risk for having not aquired capital through their K-12 educational experiences and who are, consequently, statistically most in danger of leaving college prematurely (Pancer, Hunsberger, Pratt, \& Alisat, 2000; Tinto, 1998). 
Building collegiate cultural capital, while critically important, is seldom a part of most $6-12^{\text {th }}$ grade college preparation programs, which tend to put most emphasis on academics and neglect other forms of capital nessesary for college success.

Though there is ample research examining minoritized student attrition and alienation from the university environment, this body of literature has largely ignored the need to teach the foundations underlying traditionally defined academic literacy, that is an understanding of the college system itself (Conley, 2010; Mattern \& Shaw, 2010; Perna, 2005). Kuh and Love (2000) emphasize the importance of an individual understanding and engaging with an institution's culture, and suggest that there is foundational knowledge necessary for success. However, we need more research to better understand who possesses, or fails to possess, such foundational knowledge as well as when and where this knowledge comes from. A lack of research in this area highlights how often we 'normalize' the experience of the majority of students while relegating foundational knowledge to the null curriculum. It is unfortunate that the literacies associated with academic discourse (e.g., collegiate academic literacy) and collegiate success have until now been largely ignored. Because these literacies support academic success in general, they should be an area of focus for researchers, especially in studies on retention and academic mediation at the college level. Further, it would be beneficial to understand the differing levels of academic literacy that high school teachers, counselors, and other school staff possess and how this literacy is imparted to a wide spectrum of students (and particularly for first-generation students).

To help racially minoritized and low-SES students succeed at college, we believe that college preparation programs must move beyond focusing solely on academic preparedness and the college application process, to the broader concept of college readiness that includes the 
"academic skills and practices that underlie academic performance. . .to attend college" (Arnold, Lu, \& Armstrong, 2013, p. 3). Typically, these include study skills, self-efficacy, and aspirations to attend college (Cabrera \& La Nasa, 2000; Perna, 2005; Rueda, 2005). College preparatory programs could also examine case studies (like this one) to help them identify specific areas where skill building and knowledge is needed. Some examples may be teaching students about college resources such as writing centers, students support services, and counseling services. And, also, teaching students how to access course information and how to talk to professors in person, via email, and how to engage appropriately and confidently in class discussions. Such an examination would not be complete, however, without an examination of the problematic issues minoritized and first-generation college students face when trying to adjust to the college environment (Author Citation).

\section{Implications and Reccomendations for Student Affairs}

The findings of this study have powerful implications for student affairs practice. First, it is not uncommon to find statements reflective of the institution's desire to foster environments conducive to students' academic and social success, or to promote goals such as increased student retention and recruitment of diverse populations. Perhaps the unspoken assumption is that the success in obtaining these goals is predicated by the extent to which the college can provide the resources and support needed for students to succeed. Based on the findings of this study, we argue that as educational stakeholders we may be unintentially limiting the scope of our responsibility to support students. Take, for example, Simon and Maria's reflections regarding orientation as non-helpful. It is highly possible, however, that some of the resources the participants shared that they did not have knowledge of, were introduced to them in their orientation, yet they did not, at that time, have the foundational knowledge to connect the 
information in a personal and useful way. For instance, it was not until Simon began suffering from chronic depression that he was primed to recieve the information regarding support services available from the campus health center, and connect it to himself in a meaningful way. It is important for student affairs practicioners to remember that simply providing information about services is not enough to create information connections for students to help them build literacy and, in turn, collegiate cultural capital. We suggest student affairs staff intentionally seek opportunities to make these connections for students. For example, one way to better support student development of of acadmic literacy is to be intentional about language used to connect with students in orientation and other information sessions, or via campus marketing. Using the term "free for students" as opposed to "covered with tuition", for example, may be important in communication with students from low-socioecomic backgrounds who, when they first arrive to campus, may not have the acadmic literacy foundations to equate the two term meanings.

Second, based on the findings from this study, we suggest that student affairs work collaboratively with academic affairs and enrollment services in assessment of student levels of collegiate cultural capital. It is evident that systemic barriers present well before students arrive on campus. It is also the responsibility of student affairs professionals to strive to meet students where they are, emotionally, socially, and academically. With these ideas in mind, as students who may be at risk for low levels of collegiate cultural capital are admitted, we recommend colleges assemble a team of staff from student affairs divisions, admissions offices, and acadmic advising to travel to high schools and offer basic academic literacy skills, as a proactive approach to helping these students develop and build their collegiate cultural capital foundation and prepare them to succeed in college. Meeting students in their highschools, where they are more comfortable, may help to descrease some of the anxiety or stress our participants discussed, 
resulting from feeling out of place on the college campus, and not knowing where to go for help when needed. It will also serve as a mechanism to prime students for information regarding support services they will receive during orientation or in other various points in their collegiate career.

The findings in this study highlight that without an understanding of the basic operations of the university system, students are unlikely to successfully navigate through the academic and social bureaucracy. There is a need for basic skills instruction to better prepare them for the transition to college. The downward academic spiral that each participant in this study had begun during their first semester would - without remediation in some of the basic aspects of college life-likely have continued, eventually leading to their withdrawal from the university altogether. By introducing academic literacy skills, provided by university staff, during highschool, we aim to intervene early, and better prepare students for success in college.

Finally, with the understanding that aquiring cultural capital is a process, we recommend that student affairs work together with campus assessment offices to assess growth and development of academic literacy at critical junctures in the academic career. Similar to math or writing placement tests, baseline academic literacy measures should be assessed to determine how much support students will require. Next, procedures should be followed to monitor students in their progression and provide additional assessments at critical junctures (e.g., end of the first semester, end of the first year). In addition to assessments of collegiate academic literacy, we suggest that colleges take proactive approaches to helping students succeed. That is, instead of putting the onus on the student to seek help, instead we recommend a pre-determined set of sessions with academic advisors, or assigned mentors, throughout the student's academic journey Because students 
seeking academic help or mediation are, generally, having significant academic or personal difficulties, they are sometimes reluctant to discuss these issues (Mucowski, 1984). Academic failure is, for them, often equated with deep-seeded insecurities about their intellectual abilities (Wang \& Castandenda-Sound, 2011). It is embarrassing, therefore, for many students to admit to having problems (Mucoswki, 1984; Stern, 1996). Yet through repeated contact with such students and a subsequent development of trust between a campus staff member and their student(s), problems start to reveal themselves — either through students' disclosing this information or through subtle or direct references to problem areas (Author Citation). Each of the students in our study felt like an outsider, not just because they looked different than did most other students, but because they felt "alone" in their struggles. They did not readily seek help because they had been transplanted into a paradigm into which they did not fit, but in which they were expected to succeed. They needed people with whom they could speak openly about their problems, people of whom they could ask "stupid questions" (Maria) without fear of judgment. Creating support networks is a time consuming and costly enterprise, but as this research suggests, such networks are particularly effective in helping racially minoritized, firstgeneration, low-SES students succeed . In order for the Student Academic Services Center (and services like it at other universities) to be more effective, finding more direct avenues of reaching students may be required. Email reminders of the available services could be sent to students at the start of a new semester as well as prior to mid-term and final exam weeks. Additionally, systems may need to be recalibrated to flag students whose GPAs are approaching the threshold of academic probation. 


\section{Potential Limitations}

Readers should note that the problems these students faced in their transition to college are a sampling of the myriad problems first-generation students face when entering college. Although these issues affect many students, the absence of any one or all of these issues does not mean that students are not struggling with other issues related to collegiate cultural capital (Author Citation).

Similarly, though these students shared some of the same issues, each student came to the university with individual combinations of issues that resulted in adaptive challenges.

Practitioners working with first-generation college students must be careful not to assume that the presence of any one issue means that a student or students will have any or all of the other issues. While we acknowledge that each of the socio-demographic characteristics (i.e., racially minoritized, first-generation, low-SES) can and do exist independently of the others, as discussed earlier, all three of these characteristics frequently co-exist in students who are considered to be at a "disadvantage" for postsecondary success. Consequently, this complicates the extant work on social class and makes the value-added of studies such as this harder to decipher.

Further, these students should be viewed as somewhat extreme examples of newcomers to the college community. Each self-identified (or was identified by their college academic counselor) as needing help with their collegiate-level academics. Thus they were already in academic jeopardy by the time we were working with them on this study. Two of these students were are also demographically different than most of their peers. While two students (Alex and Latricia) came to the university from large metropolitan cities, the other two (Simon and Maria) came from very rural environments where there was a dearth of college-educated mentors to whom they could turn for advice. As more students from diverse cultures enter and gain 
experience in college, it is increasingly rare for prospective college freshmen not to know someone who has college experience. Similarly, with each passing year it is increasingly rare that even first year students from low-resourced backgrounds struggle with course-related computing technology. Today's youth are increasingly “digital natives” (Prensky, 2001, p. 1) in the sense they have grown up using and oftentimes owing technology (e.g., computers, smart phones, tablets, etc.) and thus able to interact with and understand a wide variety of digital technologies. Finally, some high school programs have expanded their curricula, covering the more basic aspects of how the college system works (see Hooker \& Brand, 2009).

\section{Conclusion}

These students' educational futures - and their present level of satisfaction-would have been radically different had they not gained greater collegiate cultural capital through these hard lessons and through our work together. Unfortunately, because these resources are part of the cultural capital that too often remains hidden to relative outsiders to the university environment, countless other students continue to struggle, many believing that they are not "college material" (Latricia) and leaving college altogether. The four students who were a part of this study benefited significantly from working with "insiders" in from academic/campus environment. They gained insights to which, without intervention, they would have remained blind. How many minoritized and first-generation students, we must wonder, never learn these basic lessons and therefore suffer academic and personal failure in their attempts to reach the American dream? 


\section{References}

ACT Policy Report. (2002). School relationships foster success for African American students. (Report Number 050802040). Iowa City, IA: George Wimberly.

Adelman, C. (2006). The toolbox revisited: Paths to degree completion from high school through college. Washington, DC: U.S. Department of Education.

Arnold, K. D., Lu, E. C., \& Armstrong, K. J. (2013). The ecology of college readiness. ASHE Higher Education Report, 38(5). San Francisco: Jossey-Bass.

Aud, S., Hussar, W., Planty, M., Snyder, T., Bianco, K., Fox, M., . . Drake, L. (2010). The condition of education 2010 (NCES 2010-028). U.S. Department of Education. National Center for Education Statistics. Washington, DC: U.S, Government Printing Office.

Aud, S., KewalRamani, A., \& Frohlich, L. (2011). America's youth: Transitions to adulthood (NCES 2012-026). U. S. Department of Education, National Center for Education Statistics. Washington, DC: U.S. Government Printing Office.

Balduf, M. (2009). Underachievement among college students. Journal of Advanced Academics, 20(2), 274-294.

Barnes, W., Slate, J., \& Rojas-LeBouef, A. (2010). College-readiness and academic preparedness: The same concepts? Current Issues in Education, 13(4). Retrieved from http://cie.asu.edu/

Bartholomew, K. (2004). Computer literacy: Is the emperor still exposed after all these years? Journal of Computing Sciences in College, 20(1), 323-331. 
Benson, A. D. (2007). An exploratory study of online postsecondary education for low-income working adults: A view from education support programs. Journal of Negro Education, $76(1), 17-30$.

Bizzell, P. (1992) Academic discourse and critical consciousness. Pittsburgh: University of Pittsburgh Press.

Bourdieu, P. (1986). 'The forms of capital'. In J.G. Richardson (Ed.). Handbook of theory and research for the sociology of education. (pp. 241-58). New York: Greenwood Press.

Bourdieu, P. (1991). Language and symbolic power. Ed., J.B. Thompson. Trans., G. Raymond \& M. Adamson. Cambridge: Polity Press.

Byrd, K. L., \& MacDonald, G. (2005). Defining college readiness from the inside out: Firstgeneration college student perspectives. Community College Review, 33(1), 22-37.

Cabrera, A. F., \& La Nasa, S. M. (2000). Understanding the college-choice process. In A. F. Cabrera \& S. M. La Nasa (Eds.), Understanding the college choice of disadvantaged students (pp. 5-22). San Francisco: Jossey-Bass.

Cincinnato, S., De Wever, B., Van Keer, H., \& Valcke, M. (2016). The Influence of Social Background on Participation in Adult Education: Applying the Cultural Capital Framework. Adult Education Quarterly. https://doi.org/10.1177/0741713615626714

Chapman, L., Masters, J., \& Pedulla, J. (2010). Do digital divisions still persist in schools?

Access to technology and technical skills of teachers in high needs schools in the United States of America. Journal of education for teaching: International research and pedagogy, 36(2), 239-249. 
Charles, B. (2018). Set up to fail? How high schools aren't preparing kids for college.Governing States and Localities. Retrieved from https://www.governing.com/topics/education/govpoverty-education-college-preparedness-gao-report.html

Chen, X. (2005). First-generation students in postsecondary education: A look at their college transcripts (NCES 2005-171). U. S. Department of Education, National Center for Education Statistics. Washington, DC: U. S. Government Printing Office.

Cohron, M. (2015). The continuing digital divide in the United States. The Serials Librarian: From the Printed Page to the Digital Age, 69, 77-86.

Conley, D. (2001). Capital for college: Parental assets and postsecondary schooling. Sociology of Education, 74, 59-72.

Conley, D. (2008). Rethinking college readiness. New Directions for Higher Education, 144, 313.

Conley, D. T. (2010). College and career ready: Helping all students succeed beyond high school. San Francisco: Jossey-Bass.

Corson, D. (2001). Language diversity and education. Mahwah, NJ: Lawrence Erlbaum Associates, Publishers.

Delpit, L. (1995). Other people's children: Cultural conflict in the classroom. New York: The New Press.

Eisenberg, M. and Johnson, D. (2002). Learning and teaching information technology-Computer skills in context. ERIC Digest. (ERIC Document Reproduction Service No ED465377).

Eisner, E. (1994). The educational imagination: On the design and evaluations of educational programs $\left(3^{\text {rd }}\right.$ ed.). New York: Macmillan. 
Falcon, L. (2015). Breaking Down Barriers: First-Generation College Students and College Success $\mid$ The League for Innovation in the Community College. Innovation. Retrieved from https://www.league.org/innovation-showcase/breaking-down-barriers-first-generationcollege-students-and-college-success

Finegold, K., \& Wherry, L. (2004). Race, ethnicity, and economic well-being. Online edition. Retrieved https://www.urban.org/research/publication/race-ethnicity-and-economic-wellbeing

Freire, P., \& Macedo, D., (1987). Literacy: Reading the word and reading the world. Westport, CT: Bergin \& Garvey.

Gewertz, C. (2017). Students say schools do poor job of preparing them for college. Ed Week. Retrieved from https://blogs.edweek.org/edweek/high_school_and_beyond/2017/08/ students_say_schools_do_poor_job_preparing_them_for_college.html

Goetz, J. and LeCompte, M. (1984). Ethnography and qualitative design in educational research. Waltham, MA: Academic Press.

Henson, A. (2014). The success of nontraditional college students in an IT world. Research in Higher Education Journal, 25.

Hohlfeld, T. N., Ritzhaupt, A. D., Barron, A. E., \& Kemker, K. (2008). Examining the digital divide in K-12 public schools: Four-year trends for supporting ICT literacy in Florida. Computers \& Education, 51(4), 1648-1663.

Hooker, S., \& Brand, B. (2009). Success at every step: How 23 programs support youth on the path to college and beyond. Washington, DC: American Youth Policy Forum.

Hurd, N. M., Albright, J., Wittrup, A., Negrete, A., \& Billingsley, J. (2017). Appraisal Support from Natural Mentors, Self-worth, and Psychological Distress: Examining the 
Experiences of Underrepresented Students Transitioning Through College. Journal of Youth and Adolescence, 1-38. https://doi.org/10.1007/s10964-017-0798-x

Kim, Y. W. (2011). Minorities in higher education: 2011 supplement. Washington, DC: American Council on Education.

Kuh, G.D., \& P.G. Love (2000). A cultural perspective on student departure. In J. Braxton (Ed.), Rethinking the departure puzzle: New theory and research on college student retention. Nashville, TN: Vanderbilt University Press.

Kuh, G.D., Kinzie, J., Buckley, J.A., Bridges, B.K., \& Hayek, J.C. (2007). Piecing together the student success puzzle: Research, propositions, and recommendations. ASHE Higher Education Report, 32(5). San Francisco: Jossey-Bass.

Kutz, E. (1998). Between students' language and academic discourse: Interlanguage as middle ground. In V. Zamel \& R. Spack (Eds.), Negotiating academic literacies. Teaching and learning across cultures (pp. 37-50). Mahwah, New Jersey: Lawrence Erlbaum Associates, Publishers.

Lakoff, G. \& Johnson, M. (1980). Metaphors we live by. Chicago: University of Chicago Press.

Latham, D. \& Gross, M. (2008). Broken links: Undergraduates look back on their experiences with information literacy in K-12 education. School Library Media Research, 11.

Retrieved from https://files.eric.ed.gov/fulltext/EJ823031.pdf

Lave, J. \& Wenger, E. (1991). Situated learning: Legitimate peripheral participation. Cambridge, England: Cambridge University Press.

Mattern, K. D., \& Shaw, E. J. (2010). A look beyond cognitive predictors of academic success: Understanding the relationship between academic self-beliefs and outcomes. Journal of College Student Development, 51(6), 665-678. 
McNamara, D. \& Kintsch, W. (1996). Learning from texts: Effects of prior knowledge and text coherence. Discourse Processes, 22(3), 247-288.

Miles, M. B., \& Huberman, A. M. (1994). Qualitative data analysis: An expanded source book (2nd ed.). Thousand Oaks, CA: Sage.

Mucowski, R. J. (1984). Some common problems of new students and sources of help. Journal of College Student Person, 26(6), 550-551.

National Center for Education Statistics. (2017). Indicator 22: Degrees Awarded, (July 2017), 16. Retrieved from https://nces.ed.gov/programs/raceindicators/indicator_ree.asp

National Center for Educational Statistics. (2017b). First-generation students college access, persistence, and postbachelor's outcomes. Retrieved from https://nces.ed.gov/pubs2018/2018421.pdf

Nettles, M. \& Perna, L. (1997). The African American education data book. Volume I: Higher and adult education. Executive summary. Fairfax, VA: College Fund/UNCF. (ERIC Document Reproduction Service No. ED 406 870).

Nuñez, A-M. (2009). Latino students' transitions to college: A social and intercultural capital perspective. Harvard Educational Review, 79(1), 22-48.

Oakes, J. (2005). Keeping track: How schools structure inequality (2nd ed.). New Haven, CT: Yale University Press.

Oakes, J., Rogers, J., \& Lipton, M. (2006). Learning power: Organizing for education and justice. New York: Teachers College Press.

Ortiz, A. (1999). The student affairs establishment and the institutionalization of the collegiate ideal. New Directions for Higher Education, 105, 48-58.

Ortiz, A. (2000). Expressing cultural identity in the learning community: Opportunities and 
challenges. New Directions for Teaching and Learning, 82, 67-80.

Pancer, S., Hunsberger, B., Pratt, M., \& Alisat, S. (2000). Cognitive complexity of expectations and adjustment to university in the first year. Journal of Adolescent Research, 15(1), 3857.

Perna, L. W. (2000). Differences in the decision to attend college among African Americans, Hispanics, and Whites. Journal of Higher Education, 71, 117-141.

Perna, L. W. (2005). The key to college access: Rigorous academic preparation. In W. G. Tierney, Z. B. Corwin, \& J. Colyar (Eds.), Preparing for college: Nine elementars of effective outreach (pp. 113-134). Albany, NY: SUNY Press.

Perna, L. W., \& Thomas, S. L. (2006, July). A framework for reducing the college success gap and promoting success for all. In National Symposium on Postsecondary Student Success.

Prensky, M. (2001). Digital natives, digital immigrants. On the Horizon, 9(5), 1-6.

Pyne, K. B., \& Means, D. R. (2013). Underrepresented and in/visible: A Hispanic firstgeneration student's narratives of college. Journal of Diversity in Higher Education, 6(3), 186-198. https://doi.org/10.1037/a0034115

Quaye, S. (2007). Hope and learning: The outcomes of contemporary student activism. About Campus, 12(2), 2-9.

Redford, J., Hoyer, K. M., \& Ralph, J. (2017). First-generation and continuing-generation college students: A comparison of high school and postsecondary experience, (September 2017), 27. Retrieved from https://nces.ed.gov/pubs2018/2018009.pdf

Reid, M., \& Moore, J. (2008). College readiness and academic preparation for postsecondary education: Oral histories of first-generation urban college students. Urban Education, 43(2), 240-261. 
Rendon, L. I. (1999). Toward a new vision of the multicultural community college for the next century. In K. A. Shaw, J. R.Valadez \& R. A. Rhoads (Eds.), Community colleges as cultural texts: Qualitative explorations of organizational and student culture. Albany, NY: SUNY Press.

Ritzhaupt, A., Liu, F., Dawson, K., \& Barron, A, (2013). Differences in student information and communication technology literacy based on socio-economic status, ethnicity, and gender: Evidence of a digital divide in Florida schools. Journal of Research on Technology in Education, 45(4), 291-307.

Rueda, R. (2005). Making sense of what we know: From nine propositions to future research and interventions. In W. F. Tierney, Z. B. Corwin, \& J. Colyar (Eds.), Preparing for college: Nine elements of effective outreach (pp. 189-200). Albany, NY: SUNY Press.

Schmidt, P. (2008). A university examines underlying problems after racist incidents. Chronicle of Higher Education, 54(27), 18.

Sheehy, K. (2012). High school students not prepared for college, career. U.S. News and World Report. Retrieved from https://www.usnews.com/education/blogs/high-schoolnotes/2012/08/22/high-school-students-not-prepared-for-college-career

Smoke, K. (2013). The Effect of Parent's Education on the Educational Aspirations of College Students, 2(2011).

Solorzano, D., Ledesma, M. C., Perez, J., Burciaga, M. R., \& Ornelas, A. (2002). Latina equity in education project. Los Angeles: UCLA Chicano Studies Center. 
Sparkman, L.A., Maulding, W.S., Roberts, J. R. (2012). Non-Cognitive Predictors of Student Success in College. College Student Journal, (46), 642-653. https://doi.org/10.1080/13611260601086311

Spradley, James P. (1980). Participant observation. New York: Holt, Rinehart \& Winston. Stake, R.E. (1995). The art of case study research. Thousand Oaks, CA: Sage.

Stern, G. (1996). Myth and reality in the American college. AAUP Bulletin, 52, 408-414.

Swail, W., Redd, K., \& Perna, L. (2003). Retaining minority students in higher education: A framework for success. ASHE-ERIC Higher Education Report, 30(2). San Francisco: Jossey-Bass.

Swales, John M. (2016-03-09). Reflectiosn on the concept of discourse community. Asp. La revue du GERAS (69): 7-19. ISSN 1246-8185.

Tarchi, C. (2010). Reading comprehension of informative texts in secondary school: A focus on direct and indirect effects of reader's prior knowledge. Learning and Individual Differences, 20(5), 415-420.

Tierney, W. G. (2013). Life history and identity. The Review of Higher Education, 36(2), 255282.

Tierney, W., G., \& Colyar, J. E. (Eds.). (2009). Urban high school students and the challenge of access: Many routes, difficult paths (rev. ed.). New York: Peter Lang.

Tinto, V. (1998). Colleges as communities: Taking research on student persistence seriously. Review of Higher Education, 21(2), 167-77.

Walvoord, B. \& McCarthy, L. (1990). Thinking and writing in college: A naturalistic study of students in four disciplines. Urbana, IL: National Council of Teachers of English. 
Valdez, J. R., \& Duran, R. P. (2007). Redefining the digital divide: Beyond access to computers and the internet. The High School Journal, 90(3), 31-44.

Vygotsky, L. (1986). Thought and language. Cambridge, MA: MIT Press.

Yin, R. K. (2014). Case study research: Design and methods (5th ed.). Thousand Oaks, CA: Sage.

Zarate, M., \& Gallimore, R. (2005). Gender differences in factors leading to college enrollment: A longitudinal analysis of Latina and Latino students. Harvard Educational Revíew, 75(4), 383-408.

Zickuhr, K., \& Smith, A. (2012). Digital differences. Pew Research Center. Retrieved from https://www.pewinternet.org/2012/04/13/digital-differences/ 